\section{МЕСТНОСТЬ ӨДҮГЕН: РАСПОЛОЖЕНИЕ, ЭТИМОЛОГИЯ И СВЯЗЬ С ХАНГАЙСКИМ АНАЛОГОМ}

\section{ODUGEN: LOCATION, ETYMOLOGY AND LINKAGE WITH THE HANGAI ANALOGUE}

\author{
Андрей А. Монгуш \\ Тувинский институт комплексного \\ освоения природных ресурсов \\ Сибирского отделения Российской \\ академии наук, \\ Российская Федерация
}

\author{
Andrey A. Mongush \\ Tuvinian Institute for Exploration \\ of Natural Resources, Siberian Branch \\ of the Russian Academy of Sciences, \\ Russian Federation
}

Өдүген или Өдүген-Тайга - известное среди тувинцев название местности. Для оленеводов же Тоджинского кожууна Тувы Өдүген-Тайга является неотъемлемой частью их культуры и быта. Однако этот топоним отсутствует на топографических и любых других картах как данного района, так и всей Тувы и прилегающих сопредельных территорий. Почему топоним отсутствует, где именно он расположен, какова его этимология и как он соотносится с древнетюркским Отюкеном? В статье представлены результаты кратко$2 о$ анализа опубликованных топонимических, этимологических и фольклорных сведений о местности под названием “Өдүген” (Одуген), приведены сведения информантов из числа местных жителей Тоджинского кожууна, которых автор опрашивал в 2017 г. Проведена корреляциия полученных сведений с независимыми от них геологическими данными.

Установлено, что местность Өдуген исторически охватывала горные области Центральной Азии, на которых расположены проявления позд-

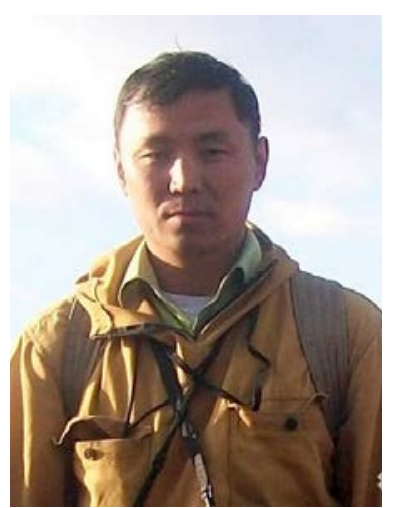

Odugen or Odugen-Taiga is a well-known territorial name among Tuvans. For the Todzhu reindeer herders of Tuva, Odugen-Taiga is an integral part of their culture and way of life. However, this toponym is absent on topographic or any other maps of the area, the whole of Tuva and adjacent territories. The article deals with the fourfold question of why the toponym does not appear on maps, where exactly it is actually located, what its etymology is and how it is relate to the ancient Turkic Otuken. We present a brief analysis of the published toponymical, etymological and cultural sources about the area called 'Өдүген' (Odugen), adding to it the information provided by the locals of the Todzhu district, who were interviewed in 2017. The obtained information is then tested against the hard geological data.

Монгуш Андрей Александрович - кандидат геолого-минералогических наук, ведущий научный сотрудник Тувинского института комплексного освоения природных ресурсов Сибирского отделения Российской академии наук. Адрес: 667007, Россия, г. Кызыл, ул. Интернациональная, д. 117а. Тел.: +7 (923) 387-37-62. Эл. адрес: amongush@inbox.ru

Mongush Andrey Aleksandrovich, Candidate of Geology and Mineralogy, Leading Researcher, Tuvanian Institute for the Exploration of Natural Resources, Siberian Branch, Russian Academy of Sciences. Postal address: 117a International St., 667007, Kyzyl, Russian Federation. Tel.: +7 (923) 387-37-62. E-mail: amongush@inbox.ru. ORCID: 0000-0002-9299-086X 
некайнозойского вулканизма. К этим областям относятся большая часть территории горных систем Восточного Саяна и Хангая. Исторические и фольклорные сведения о расположении данного топонима и геологические данные о наиболее молодом вулканизме указывают на одни и те же местности в Восточном Саяне и Хангае. Этимология слова филологами делится на три составные, которые образованы присоединением к тюркской глагольной основе 'өт' (в значении 'испражняться'), отыменного аффикса '(а)к' (өт+(a) к > өдек: навоз; шлак, лава [вулканические]; ...) и форманта '(а)н', дающего имя собственное: өт+(a) ${ }^{+}($a)н $>$өдүген. Таким образом, автор полагает, что “Өдүген” обозначал территорию, содержащую продукты вулканических извержений - вулканические лавы и шлаки - "испражнения" Земли.

Ключевые слова: Тува; Одуген; Өдуген; Тоджа; Восточный Саян; Хангай; тувинский язык; топонимия; топоним; этимология; вулкан; геология
It is proved that historically the area named Odugen covered the mountain regions of Central Asia, which showed manifestations of late Cenozoic volcanism. These areas include most part of the mountain systems of Eastern Sayan and Khangai. Historical and folk information about the location of this toponym and geological data on the youngest volcanism both point to the same areas in the Eastern Sayan and Khangai. Linguists have discovered three elements in the etymology of the word, which was formed by joining the Turkic verbal stem ' $\theta t$ ' (meaning 'to defecate'), noun affix '(a)k' $(\theta t+(a) k$ > $\theta$ dek: manure; slag, lava [volcanic]; ...) and proper name formant '(a)n': $\theta t+(a) k+(a) n>\theta d u g e n \sim$ odugen. Thus, we hold that "Odugen" meant the area containing the products of volcanic eruptions - volcanic lava and slag the "excrement" of the Earth.

Keywords: Tuva; Odugen, Odugen-Taiga, Todzha; East Sayan; Khangai; Tuvan language; toponymy; place name; etymology; volcano; geology

\section{Введение}

Өдуген или Өдуген-Тайга - известное среди тувинцев название местности, которая находится в Тоджинском кожууне. Правда многие тувинцы понимают под этим названием расположенную в Туве часть горной системы Восточного Саяна, а оленеводы самого кожууна - лишь только высокогорное плато в верховьях Большого Енисея и Хамсары.

Для оленеводов же Тоджинского кожууна Тувы, в частности, оленеводческой общины “Өдүген”, Өдүген-Тайга является неотъемлемой частью их культуры и быта. Вот что нам сообщил в июне 2017 г. бывший председатель этой общины М. Б. Севек ${ }^{1}$ :

«Өдүген-Тайга бистиң чуртувустуң хүн үнер чүгүнде чыдар, Барааннарның чиңгине чурту, чурттап чораан черлери-дир, ивижилерниң, чылгычыларның чайлаглары-дыр. Өндүр улуг тайга. Өдүгенниң хүнгээр талазында бир ужу“Пик Топографов", тыва ады - Хар-Тайга, эривес харлыг, меңгилиг тайга. Өдүгенниң үстүнде, мурнуу талазында Өгбе-Тайга бар. Булуң-Өдүген деп чер бар - ол Өдүгенниң бир булуну бооп турар. Арга-Өдүген, Ий-Өдүген деп черлер база бар. Белин хем Өдүген-Тайгадан агып чыдар».

Перевод с тувинского языка:

«Одуген-Тайга в нашей земле расположена в стороне восхода солнца, это

\footnotetext{
${ }^{1}$ Севек Михаил Бавууевич, 1979 г. р., житель села Адыр-Кежиг Тоджинского кожууна.
} 
исконные земли племени Бараан, там они жили, это летники оленеводов, табунщиков. Очень большая тайга. В солнечной стороне Одугена есть пик Топографов, его тувинское название - Хар-Тайга, на нем не тает снег. В верхней части Одугена, в передней ${ }^{1}$ стороне, есть Огбе-Тайга. Булун-Одуген это один из уголков Одугена. Есть также местечки Арга-Одуген, Ий-Одуген ${ }^{2}$. Река Белин течет с Одуген-Тайги».

Отметим также, что, согласно «Топонимическому словарю Тувы» Б. К. Ондар, Өдүген представляет собой гору, хребет, находящиеся в Тоджинском кожууне (Ондар, 2007: 330).

Вместе с тем, однако, этот топоним отсутствует на топографических и любых других картах данного района.

Возникают вопросы: почему отсутствует, где именно он расположен, какова его этимология и как он соотносится с древнетюркским Отюкеном?

Цель статьи заключается в анализе опубликованных топонимических, этимологических и фольклорных сведений о местности под названием Өдуген (Одуген), в выявлении ее расположения, в рассмотрении существующих вариантов этимологии данного топонима и выборе наиболее реального непротиворечивого варианта, а также в сопоставлении данного топонима и с древнетюркским названием сакральной местности Отюкен. Источниковую базу статьи составляют данные авторского опроса среди местных жителей Тоджинского кожууна 2017 г., сведения, почерпнутые из опубликованных трудов: этнографа С. И. Вайнштейна (Вайнштейн, 1961), историков Ю. И. Дробышева (Дробышев, 2012), Л. П. Потапова (Потапов, 1957), лингвиста Б. И. Татаринцева (Татаринцев, 2008), геоморфолога М. Г. Гросвальда (1965), геологов В. В. Ярмолюка, С. Г. Аржанникова, С. Г. Прудникова, А. М. Сугораковой и других (Ярмолюк и др., 2004, 2008, 2011; Аржанников и др., 2017, Прудников, 2005; Сугоракова, Монгуш, 2015), а также информация из средств массовой информации Тувы. Проведена корреляция полученных исторических, фольклорных, этимологических сведений с независимыми от них геологическими данными.

\section{Расположение местности “Өдүген”}

По сведениям С.И. Вайнштейна, «тоджинцы считали некоторые горы с безлесными плоскими вершинами священными. Особой известностью пользовался горный массив Одуген (Өдуген) в верховьях рек Хам-Сыры и Азас, значительная часть которого была плоской и безлесной. В Одугене священными

\footnotetext{
${ }^{1}$ Как я заметил, тувинцы-тоджинцы, в отличие от большинства современных тувинцев, до сих пор передней стороной (мурнуу тала / чүк) называют не юг, а восток. Кроме того, Большой Енисей они называют не Бий-Хем, а Улуг-Хем.

${ }^{2}$ Хар-Тайга - 'снежная тайга', Өгбе-Тайга - 'тайга предков’, Арга-Өдуген - 'лесной Одуген', ИйӨдуген - 'склоновый Одуген'.
} 
считались шесть гор: Дээрби-Тайга, которая была наиболее почитаемой, КараТайга, Ова-Тайга, Кошке-Тайга, Шивит-Монгур, Добулер-Тайга» (Вайштейн, 1961: 174; курсив источника. - A. М.).

Л. П. Потапов сообщает, что хребет под названием “ўтӱген” расположен в верховьях Большого Енисея (Бий-Хема), на нём берут начало р. Баш-Хем, левый приток Бий-Хема, и р. Азас, впадающей в озеро Тоджи-Куль. Этот хребет обозначен на некоторых старых картах как “Хуку-Дайга” или “Кхуку-Тайга” .

«Ни один из путешественников, в том числе и географов, проезжавших в районе этого хребта, не зафиксировал его настоящего наименования

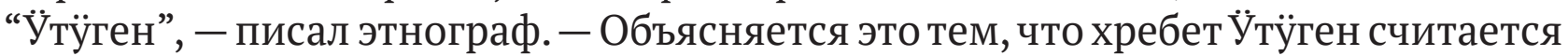
у местных тувинцев священной почитаемой горой - “Улуг-Тайга”, собственное имя которой, согласно их религиозным воззрениям, нельзя было произносить в присутствии посторонних» (Потапов, 1957: 112).

Таким образом, существованием у тувинцев-тоджинцев запрета на произношение названия “Өдуген” в присутствии посторонних лиц можно объяснить отсутствие этого топонима на картах.

В монографии М. Г. Гросвальда фигурируют названия “Булун-Утуген” и “УлугУтуген” 2 . Согласно его описанию, “плато Булун-Утуген занято самым большим в Туве непрерывным полем кайнозойских базальтов, площадь которого

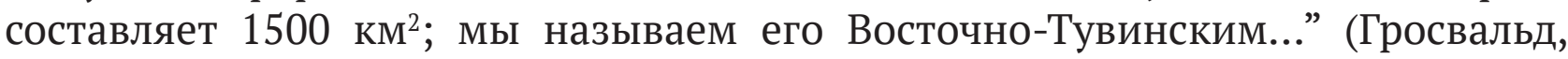
1965: 89-90). К плато Улуг-Утуген относятся “горы Плоская и Кок-Хемская на водоразделе Большого Саяна, гора Приозерная к северу от оз. Кара-Балык, гора

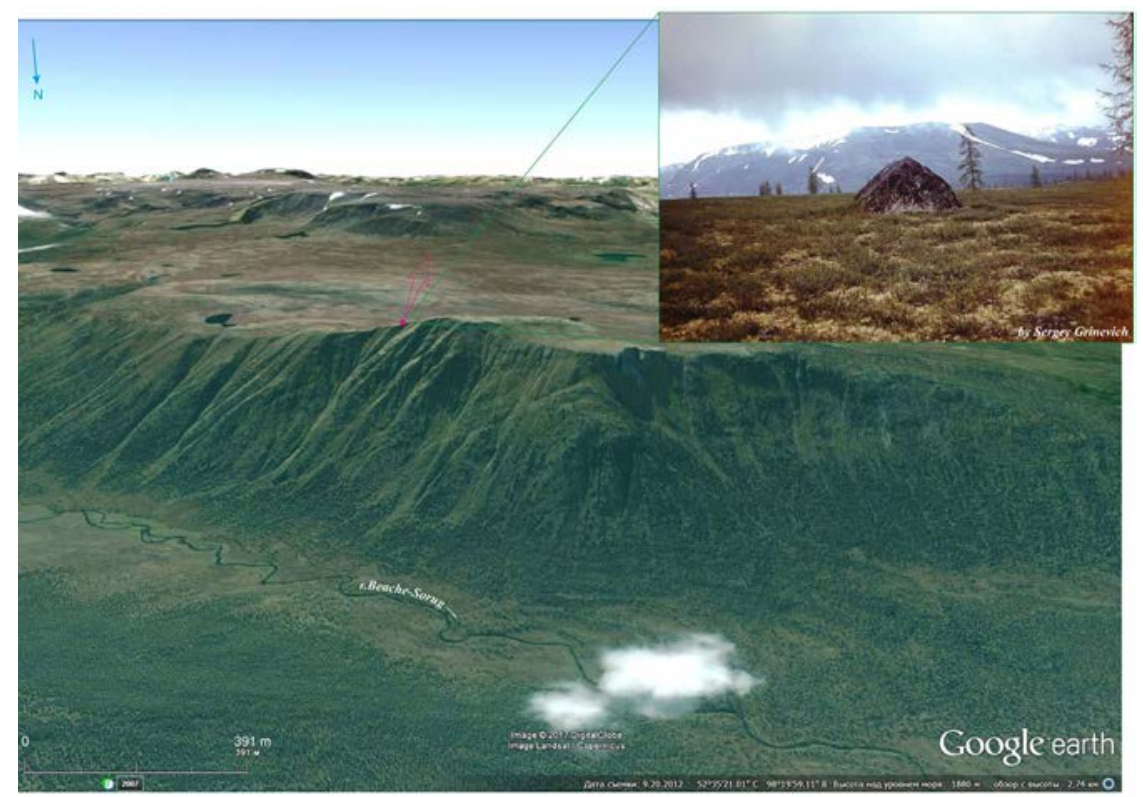

Рис. 1. Центральная часть Восточно-Тувинского лавового нагорья. В лавовое плато врезана долина р. Биче-Соруг. На врезке - «Лавовое плато Булун-Утуген, на заднем плане щитовой вулкан Шивит-Тайга», по С. Гриневичу. Фото Google Earth, дата съемки 2012 2. Красная точка и стрелка - место и направление фотосъемки.

Fig. 1. The central part of the EasternTuva lava highland. The Biche-Sorug river valley is incised in the lava plateau. In the sidebar, Bulun-Utugen lava plateau, with shield volcano Shivit-Taiga in the background, as in S. Grinevich (photo courtesytGoogle Earth). The red dot and arrow indicate the location and the direction of photography.

\footnotetext{
${ }^{1}$ На современных картах - 'Ку-Тайга', показан в междуречье рр. Большой Енисей - Баш-Хем.

${ }^{2}$ Эти названия на тувинском языке звучат как Булуң-Өдүген ('уголок Одуген’) и Улуг-Өдүген ('Большой /Великий Одуген').
} 
Кадыр-Тайга в 5 км к северо-западу от того же озера” (там же: 91).

Эти сведения указывают на то, что лавовое плато Булун-Утуген заключено в междуречье верхнего течения рек Большой Енисей и Хамсара, а лавовое плато Улуг-Утуген является продолжением Булун-Утугена на восток до водораздела бассейна pр. Большой Енисей - Ока. Типичные ландшафты данного района показаны на рисунках 1-3.

С этими данными о расположении рассматриваемого топонима практически согласуются сведения местного жителя С. А. Квитных ${ }^{1}$, полученных нами в 2017 г.:

«Плато Одуген находится между верховьями р. Соруг и верховьями Большого Енисея. Там нет дров, при переходе через плато дрова на одну ночевку брали с собой. Раньше мне казалось, что название произносится 'Удуген', а теперь знаю, что правильнее - 'Одуген'».

Өдүген упоминается, в том числе и в стихотворной форме, в очерке Елены

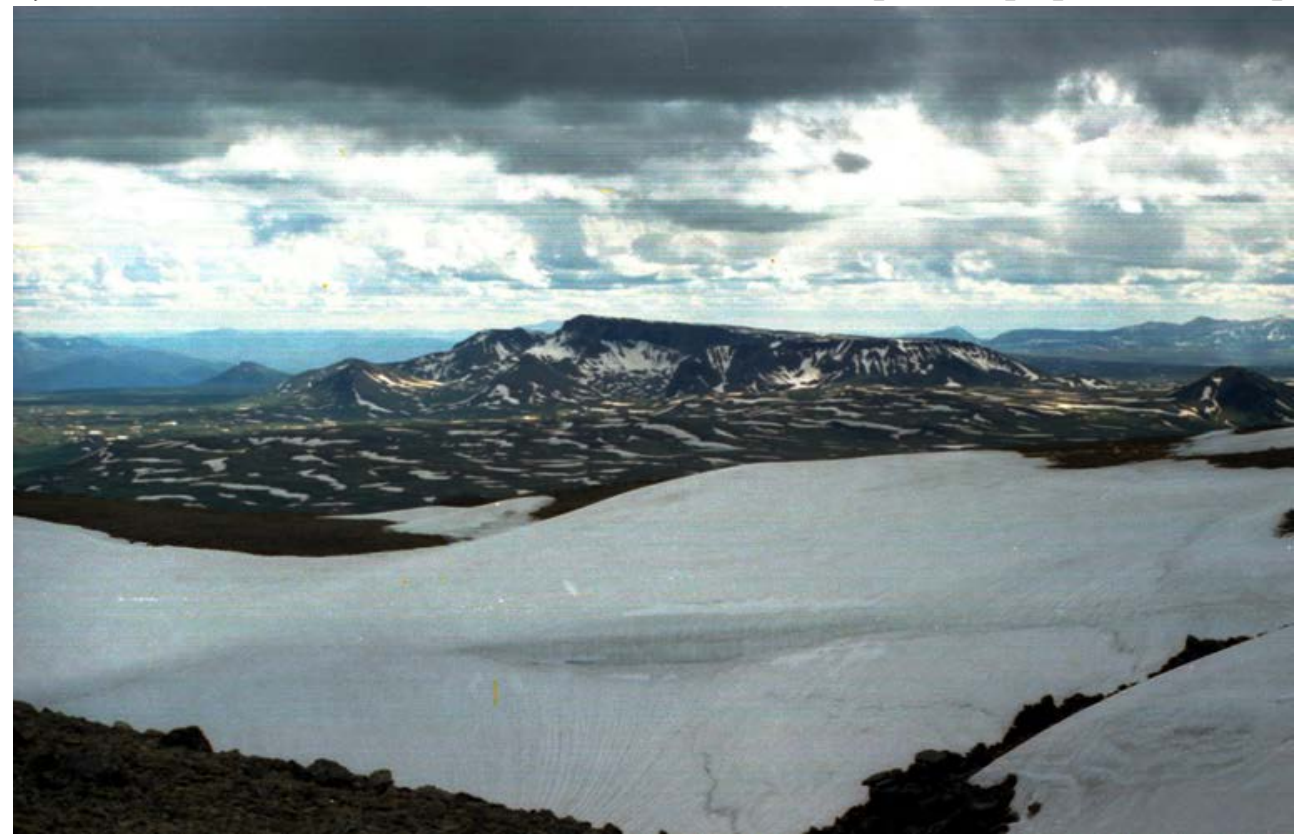

Рис. 2. Вулкан Дерби-Тайга². Фото А. Сугораковой, 1998 г.

Fig. 2. Derbi-Taiga volcano. Photo by A. Sugorakova, 1998.

Чадамба, посвященном ее отцу Леониде Чадамба (1918-1987):

«Во время каникул Чадамба преподаёт в летних школах в своём родном Тоджинском районе, сначала в местечках Талым, Толбул, а затем - в отдалённом Одугене, где жили оленеводы... На Одугене, в тайге Кош-Пош, был у меня ученик хорош... Впору запеть! В стихах воспоёшь, чудо в далёкой тайге Кош-Пош...» (Чадамба, 2014: Электр. ресурс).

\footnotetext{
${ }^{1}$ Квитных Сергей Анатольевич, 1969 г. р., с малых лет жил в селе Чазылар (Хамсара) Тоджинского кожууна.

${ }^{2}$ От тув. дээрбе - 'мельница'.
} 


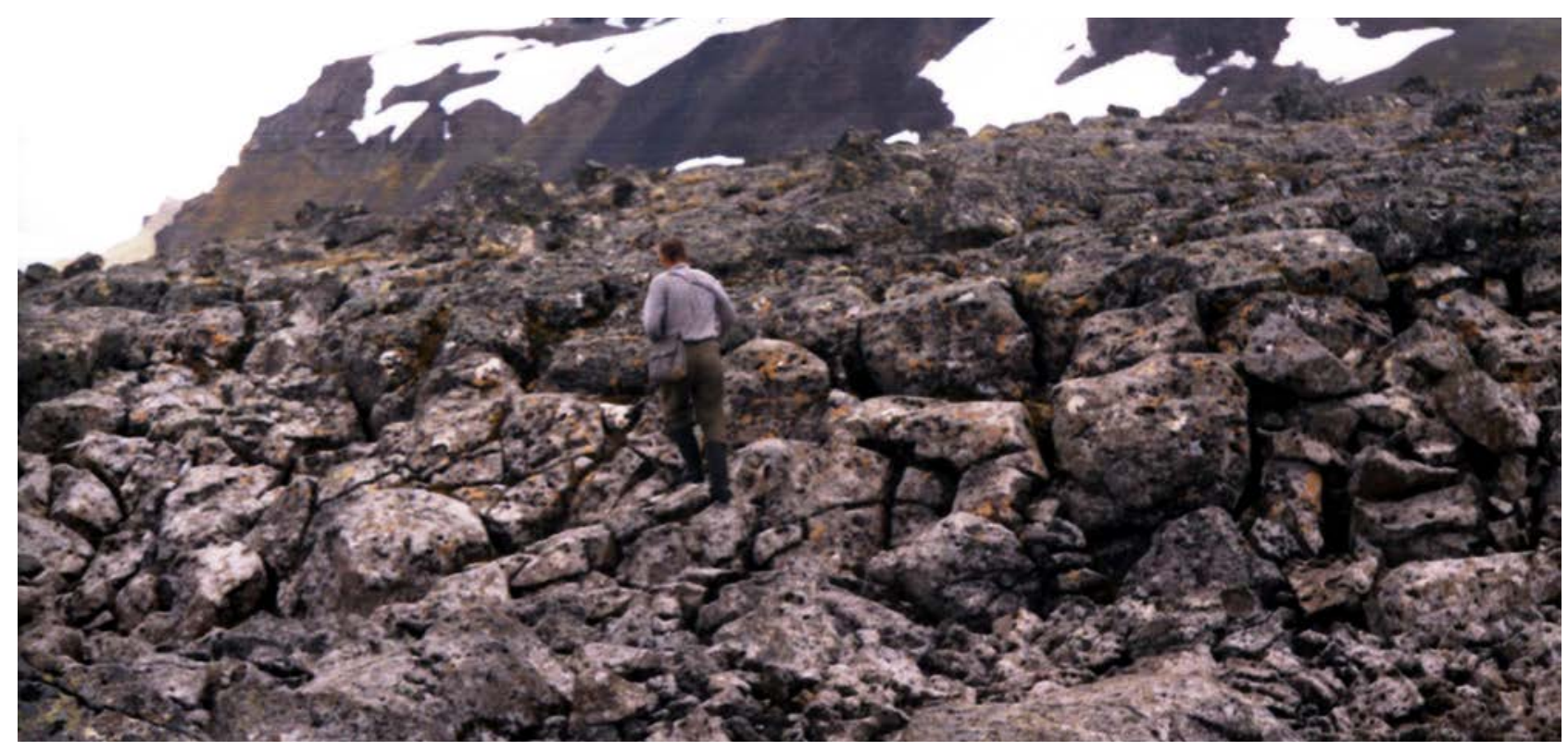

Рис. 3. Лава базальтов вулкана Шивит-Тайга1. Фото А. Сугораковой, 1998 г.

Fig. 3. Basalt lava of Shivit-Taiga volcano. Photo by A. Sugorakova, 1998.

В данном случае речь идет, очевидно, о топониме Кош-Пөш (спаренный, двойной кедр), представляющем собой название местности, речки в системе хребта Өдүген в Тоджинском кожууне (Ондар, 2007: 255). Данные сведения нуждаются в уточнении, поскольку есть две речки Кош-Пөш, текущие в верховьях рр. Улуг-Баш-Хем и Кижи-Хем, и обе эти местности до сих пор служат летними пастбищами оленей родовых общин Өдүген (Улуг-Баш-Хем) и Шулун (Кижи-Хем).

Содержательные сведения о расположении местности Өдуген нам сообщил С. М. Оюн ${ }^{2}$ в мае 2017 г.:

«Өдүген-Тайга дээрге дыка улуг чер-дир ийин. Шинчилеттинмээн. ТоораХемден Чойган аржаанынче аъттыг үнер болза Өдүген-Тайга Улуг-Баш-Хемде Меңги-Хөлден эгелей бээр. Чойган аржааны Өдуген-Тайгазынче база кирип турар. Соңгу талазында Кижи-Хем тайгалары база Өдүгенге хамааржыр, мурнуу талада Үш-Бельдырге (Белдирге) чедир чаттылган. Эргек-ДыргакТайганың чөөн чүкче уламчызы-дыр, оон мурнуу чүкче, Үи-Бельдир талазынче ээn чоруй баар. Бээр Тофаларияның, Бурятияның болгаш Моолдуң черлери база кupun mypap».

Перевод с тувинского языка:

«Одуген-Тайга - это очень большая земля (территория).Она не исследована. Если выезжать верхом на лошадях из поселка Тоора-Хем на аржаан Чойган,

\footnotetext{
${ }^{1}$ Шивит - 'охра’.

${ }^{2}$ Оюн Сергей Мартый-оолович, 1967 г. р., уроженец Тандынского кожууна, долгое время жил в пос. Тоора-Хем Тоджинского кожууна, ныне - шаман шаманской организации “Адыг-Ээрен - Дух Медведя", г. Кызыл.
} 
то Одуген-Тайга начинается с озера Менги-Холь на р. Улуг-Баш-Хем. Аржаан Чойган тоже входит в Одуген-Тайгу. С севера таежные места бассейна р. Кижи-Хем тоже относятся к Одугену, он расстилается до Уш-Бельдыра на юге. Одуген-Тайга является восточным продолжением хребта Эргек-ДыргакТайга, потом поворачивает на юг, в сторону Уш-Бельдыра (слияние рр. Билин, Шишгид-Гол, Бусийн-Гол). Сюда (к Одуген-Тайге) также относятся земли Тофаларии, Бурятии и Монголии».

В 2006 г. ИА “Тува-Онлайн” опубликовал вопрос японца Мосохико Тодорики:

«В альбоме “Плач сироты” (The Orphan's Lament) группы “Хун-Хурту” есть очень красивая песня “Одуген-тайга”. В некоторых книгах я нашел указание

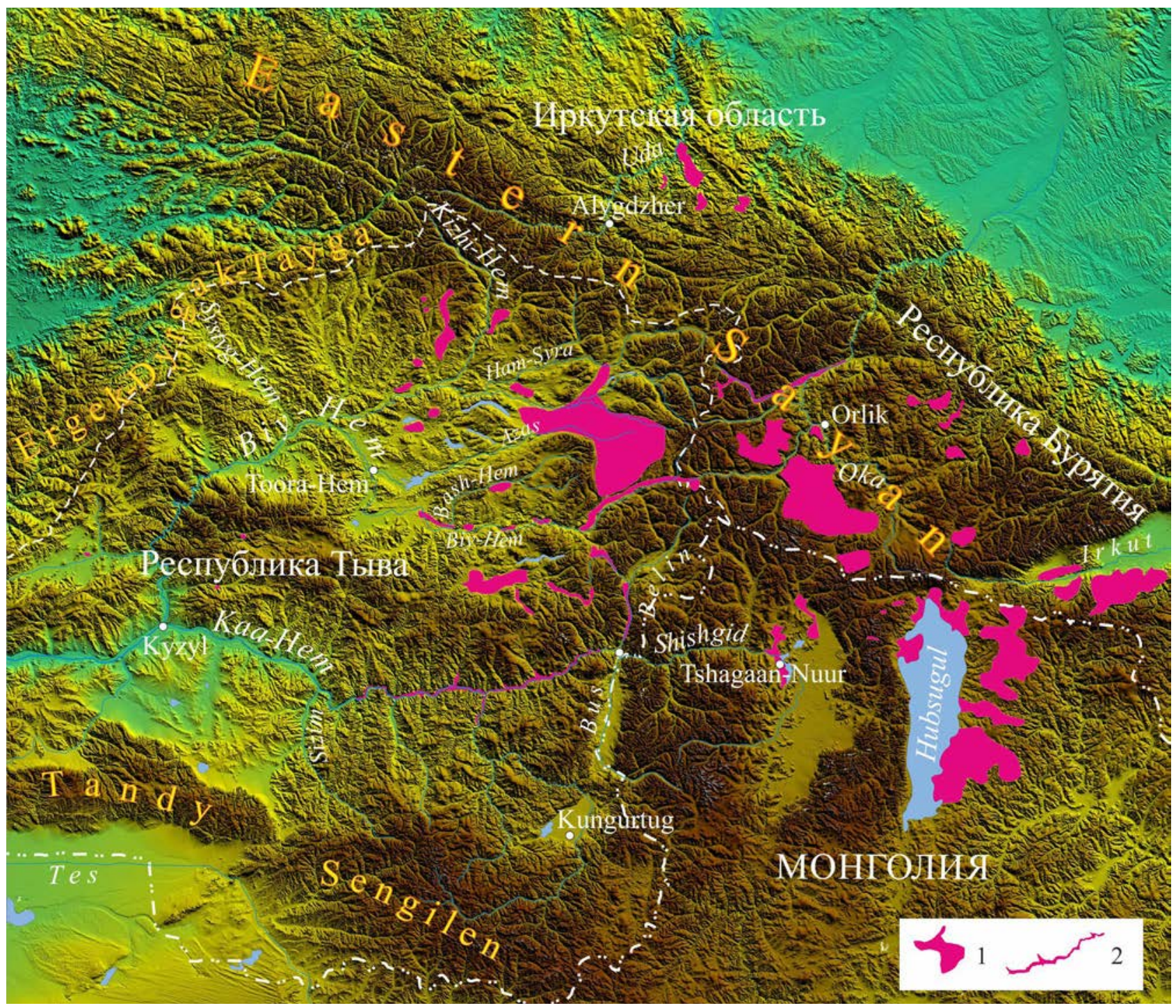

Рис. 4. Позднекайнозойский вулканический ареал Восточного Саяна. Лавовые плато (1) и «реки» (2). Карта составлена автором на основе предоставленного О. Д. Аюновой космоснимка. Fig. 4. Late Cenozoic volcanic area of the Eastern Sayan. Lava plateaux (1) and "rivers" (2). Map prepared by the author based on photos from space courtesy of O. D. Ayunova. 
на то, что это горный хребет в Тодже (Ондар Б. К. Топонимический словарь, ХакГУ, Абакан, 2004; Тенишев Э. Р. Тувинско-Русский словарь, Советская энциклопедия, Москва, 1968). Но нигде не указывается месторасположение Одуген-тайги. Не упоминается она и на многочисленных картах Тувы, которые у меня есть. Может ли кто-нибудь в Туве подсказать, где же находится Одуген-тайга» (Оюн, 2006: Электр. ресурс).

Ответ на него был следующий, со ссылкой на редакцию газеты «Шын»:

«...По словам жителей Тоджи, от Одуген-Тайги берут свои начала два больших истока Б. Енисея (Бий-Хема): Сыстыг-Хем и Азас. Между началами этих рек находится основная часть Одуген-Тайги. Она располагается в северной части Тоджи и граничит с Иркутской областью, часть ее территории сопредельна с Монголией» (там же).

Итак, Өдүген, согласно бо́льшей части вышеприведенных сведений, локализован в районе, заключенном между верхними течениями рек Хамсара $(Х а м-С ы р а)$ и Большой Енисей (Бий-Хем). Важно отметить, что именно в этом районе сосредоточено большое количество проявлений вулканизма позднекайнозойского, т. е. наиболее молодого в геологическом отношении, возраста (рис. 4). Другие сведения указывают на то, что в Өдүген, помимо указанного района, входят также горные области от верховьев рр. Сыстыг-Хем и Кижи-Хем (стык Западного Саяна с Восточным Саяном) до Уш-Бельдыра (слияние рр. Белин, Шишхид и Бус), включающие пограничные территории Тувы с Иркутской областью, Республикой Бурятией и Монголией.

Таким образом, Өдүген расположен в Северо-Восточной Туве на юго-западных отрогах Восточного Саяна, либо, в расширенном варианте, на большей части территории Восточного Саяна.

В традиционной тувинской топонимике отсутствует ороним Саян (см.: Ондар, 2007). Это видно также из статьи большого знатока традиционной тувинской культуры, в т. ч. топонимики, К. Т. Допчун-оола, в которой он пишет: “Тувинский артыш растет в горно-таежных районах Тувы: на севере - хребты Хаан-Дээр, Самына, Эргек-Дыргак-Тайга, Одуген, на юге - Танды, на востоке Хаан-Тайга, Кунгуртуг, на западе - Бай-Тайга” (Допчун-оол, 2015: 34). Здесь перечисление названий горных хребтов идет с северо-запада на северо-восток Тувы (Хаан-Дээр - Одуген), затем - с юго-запада на юго-восток Тувы (Танды Кунгуртуг), наконец - запад Тувы (Бай-Тайга). Если первые три оронима - ХаанДээр, Самына, Эргек-Дыргак-Тайга - составляют горную систему Западного Саяна, то Өдуген должен охватывать Восточный Саян.

Вполне возможно, что Өдуген - традиционное тувинское название (эндоним) Восточного Саяна. А 'Саян', как Западный, так и Восточный, как известно, является названием, данным соседями по названию племени Соян 
(Вайнштейн, 1961: 38)1․ Показательно, что собранные С. И. Вайнштейном сведения о тувинцах-тоджинцах указывают на расселение в середине XIX века носителей этнонима Соян в северо-восточной части Тоджи (Вайнштейн, 1961: схема-вкладка).

Первые документальные сведения о “Саянской земле”, точнее, о западной части Саян, датируются началом XVII века. По расспросам казаков В. Тюменца и И. Петрова, в 1615 г. проехавших по маршруту г. Томск - оз. Убсу-Нуур и обратно, записано следующее:

“...А ис Табинские земли шли оне на Саянскую землю, а в ней князек КараСакул с товарыщи; живут себе меж гор и лесов по речкам; горы каменые, а леса черные, большие; а сколько их всех, того им сметить было нельзе, потому что живут в розни; а слухом оне про них слышели, что их с 5000 человек. А ездят на оленях и на конях, а ясак дают Алтыну ж царю. А житье их то ж, что и в Табынской земле: угодей никаких нет, и хлеб не родитца... И Саянские земли князек Кара-Сакул с товарыщи... подводы присталые переменили, а на корм дали мяса оленья довольно... А шли оне ис Табинские земли до Саянские земли 7 ден. А тою дорогою перешли оне в те 7 ден трои горы каменые, а лежат на них снеги зимою и летом безпрестанно, и оболока на тех горах лежат, и стужа на них живет во все лето. А от Алтына-царя Саянская земля за 10 ден. А из Саянские земли шли оне до Матцкие земли 8 ден, а места были ровные, меж гор же, а горы были им по сторонам (Расспросные ..., 1617: 8-10)².

\section{Об этимологии названия “Өдуген”}

Из “Этимологического словаря тувинского языка” Б. И. Татаринцева следует, что «Өдүген [өъ] тоджинский диалект 'обширная территория в горах с относительно ровной поверхностью, каменистой почвой, безлесная, поросшая ягельником и служащая пастбищем для оленей; обширная безлесная равнина в горах’» (Татаринцев, 2008: 360; курсив источника. - A. M.).

\footnotetext{
${ }^{1}$ Соян - одно из тувинских племен. Хакасы Туву называли Соян, тувинцев - соян кижи, а Саянские горы - соян таглары (Субракова, 2006: 487). Существует также точка зрения о том, что этноним ‘сойон’ означает “народ, почитающий оленя как предка”, где ‘со’ - олень, ‘йон' ‘чон' - народ; ‘Со’ - известное из древнекитайских источников название родины народа Тоба, а 'Со-лу’ на древнекитайском - “дикие люди из страны Со” (Доржу, 2015: 21).

${ }^{2}$ Как видно, все названные казаками земли образованы от этнонимов - Туба (Табинские земли), Соян (Саянские земли), Маады (Матцкие земли). Отметим также, что “снега и стужа во все лето” на упомянутых Саянских горах - благоприятный фактор для оленеводства. Видимо, в историческом прошлом Саянские горы были населены племенами с единым хозяйственно-бытовым укладом (охота, оленеводство и др.), ныне представленный коренными жителями Тоджинского и ТереХольского кожуунов Республики Тыва, р. Ус (Красноярский край), тофаларами (Иркутская область), сойотами (Бурятия), цаатанами и дархатами (Монголия).
} 


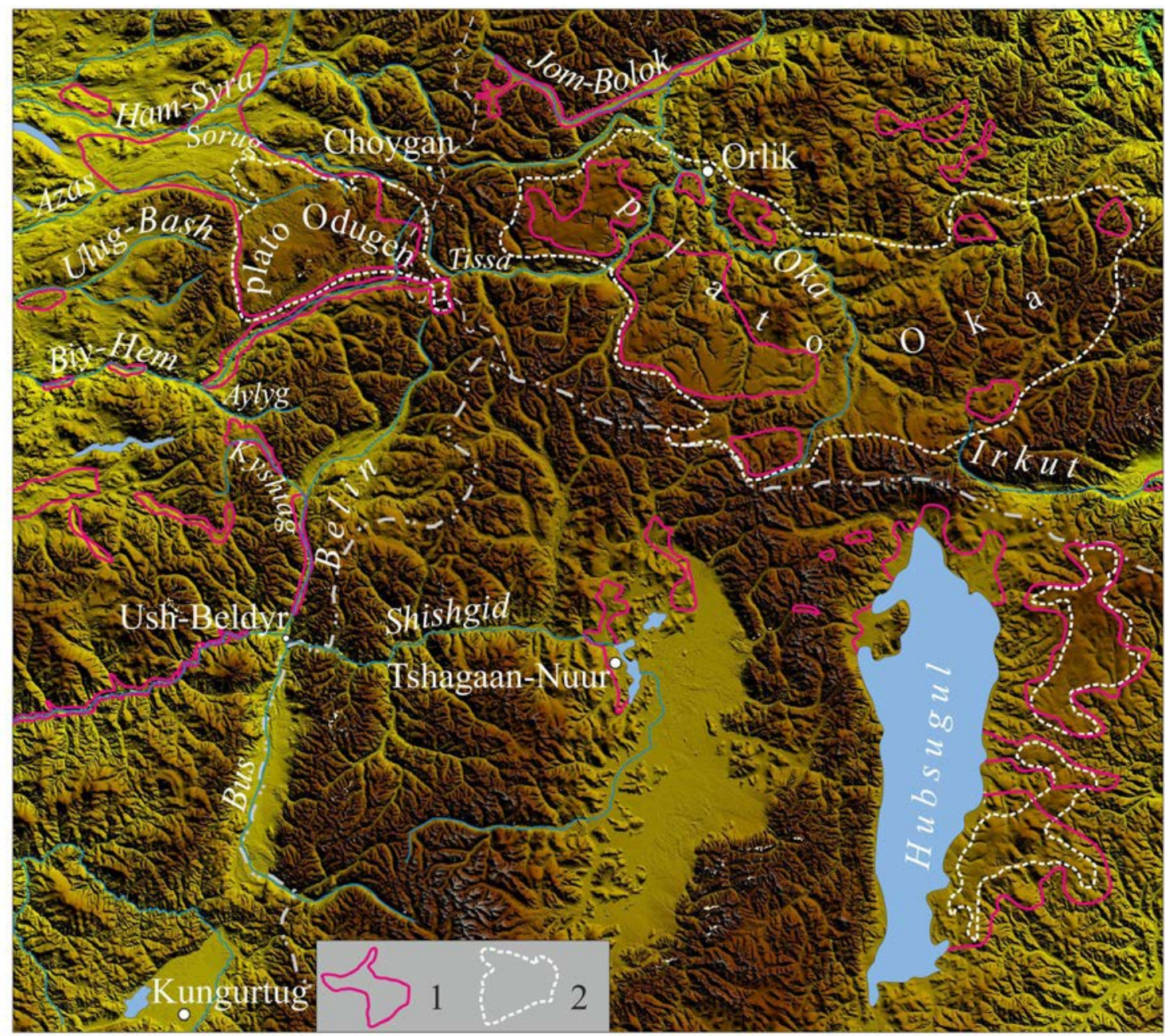

Рис. 5. Соотношение лавовых (1) и горных плато (2). Карта составлена автором на основе предоставленного О. Д. Аюновой космоснимка.

Fig. 5. The correlation between the lava plateaux (1) and the regular plateaux (2).

Map prepared by the author based on photos from space courtesy of O. D. Ayunova.

Перечисленные признаки - относительно ровная, каменистая, безлесная территория в горах - характеризуют горное плато ${ }^{1}$. А горные плато в пределах Восточного Саяна обычно представляют собой лавовые плато, т. е. их поверхность сложена вулканическими лавами (рис. 4, 5).

Эта взаимосвязь местности Өдуген с типом вулканического тела согласуется с ранее высказанным мнением Т. Н. Прудниковой о том, что «священное нагорье Отукен является не чем иным, как вулканическим плато, а одиночные священные горы - вулканическими центрами» (Прудникова, 1997: 214). И в недавней своей работе она подчеркивает, что притягательность и сакральность территории Одуген обусловлена вулканическими процессами на глазах древнего человека (Прудникова, 2017).

\footnotetext{
${ }^{1}$ Плато́ (фр. plateau, от plat - «плоский») - возвышенная равнина с ровной или волнистой слабо расчленённой поверхностью.
} 
Существует версия о том, что өдүген может иметь значения: 1) өт үнген - с тувинского дословно означает 'желчь выходящая', и/или 2) от үнген - 'огонь выходящий’ (устное сообщение А. А. Соскала', октябрь 2016 г.). Как пояснил Айбек Александрович, в древности өт үнген могло использоваться местными жителями в отношении места, извергающей вулканическую лаву, а от үнген обозначал огненные всполохи, выходящие из кратера действующего вулкана. Семантика слов өт - 'желчь' и 'лава', с одной стороны, в какой-то мере близка - оба представляют горькую и горячую жидкости, образующиеся из твердого вещества - печени (желчь) и мантии (лава), соответственно. С другой стороны, желчь - это реагент, имеющий в живых организмах весьма активную функцию, чего нельзя сказать о вулканической лаве, взаимодействие которой с окружающей средой не столь активное. Поэтому, даже образное сравнение желчи с лавой нам представляется не совсем верным. Что касается от үнген в значении 'извергающий огонь', то оно могло обозначать действующий вулкан. А предки современных тувинцев и их восточных соседей определенно были знакомы с ним, о чем свидетельствуют легенды местных оленеводов.

Но вначале дадим небольшую геологическую справку. На северо-востоке и востоке Тувы, а также на сопредельных территориях Иркутской области, Бурятии и Монголии распространены позднекайнозойские вулканические породы - базальты, возраст которых исчисляется от десятков миллионов до одной тысячи лет. Базальтовые тела слагают: а) лавовые плато со щитовыми вулканами, из них наиболее крупное представлено Восточно-Тувинским лавовым нагорьем в истоках рр. Хамсара, Азас и Большой Енисей, б) шлаковые вулканические конусы, например, вулканы Кропоткина и Перетолчина в верховьях р. Жом-Болок, в) расположенные в современных речных долинах многочисленные лавовые “реки”2, например, самая длинная в мире лавовая “река” в долине рр. Кызыл-Хем, Каа-Хем, протягивающаяся на 175 км от района Уш-Бельдыра до устья Сизима (Сугоракова и др., 2003; Ярмолюк и др., 2004; Прудников, 2005; Аржанников и др., 2017).

Одна из таких лавовых “рек”, расположенная в долине реки Кыштаг (рис. 5), согласно фольклорным данным, была образована в историческое время.

\footnotetext{
${ }^{1}$ Соскал Айбек Александрович, 1966 г. р., ветеринарный врач, живет в г. Кызыл Республики Тыва, исследователь истории культуры тувинского народа (записано с его слов 10.07.2018, запись хранится в архиве автора статьи).

${ }^{2}$ Специфика лавовой “реки” заключается в том, что вулканический аппарат располагается в речной долине, а последняя всегда наследует тектоническую зону разлома, вверх по которой из недр и устремляется магма. Поэтому извергающаяся лава “вынуждена” течь вниз по речной долине на десятки и сотни километров. Лавовые “реки” Центральной Азии (бассейны рек Большого и Малого Енисея, Оки, речные долины Ар-Хангая) отличаются также от лавовых плато более молодым возрастом - их возраст составляет менее 3 млн лет, а возраст лавовых плато данного региона древнее 3-4 млн лет. Это обусловлено тем, что в интервале времени между 4 и 3 млн лет назад началось горообразование, охватившее регионы Саян и Хангая, т. е. ранние обширные горизонтально лежащие лавовые плато сменились поздними долинными лавовыми потоками (Ярмолюк и др., 2008).
} 
А. М. Сугоракова, будучи геологом Билинской геолого-съемочной партии Тувинской геологоразведочной экспедиции, летом 1983 г. из уст пожилого тувинца-оленевода по имени Анарат (?) слышала легенду следующего содержания:

«В старые времена здесь жило много людей. Тут, на реке Кыштаг, большое племя, и недалеко, на реке Айлыг, еще одно племя. Случился в один год мор в племени реки Айлыг, от лихой болезни умерли почти все, а когда мор кончился, в живых остались лишь несколько детей и одна старуха. Взрослых нет, кормить детей некому. И повела старуха детей в земли племени на реке Кыштаг. Едва живые добрались они до реки Кыштаг и попросили приютить их. Но люди племени Кыштаг ${ }^{1}$ испугались, что худая болезнь придет к ним тоже, и погнали пришельцев вон. Старуха, отчаявшись спасти последних детей своего племени, встала на скалу и произнесла ужасные слова проклятия. Как только прозвучали последние слова, сливаясь с ними, раздался утробный гул из-под земли, она раскрылась, и оттуда вырвались огненные волны. И потекли по реке Кыштаг вместо воды огненные потоки, и сожгли они все

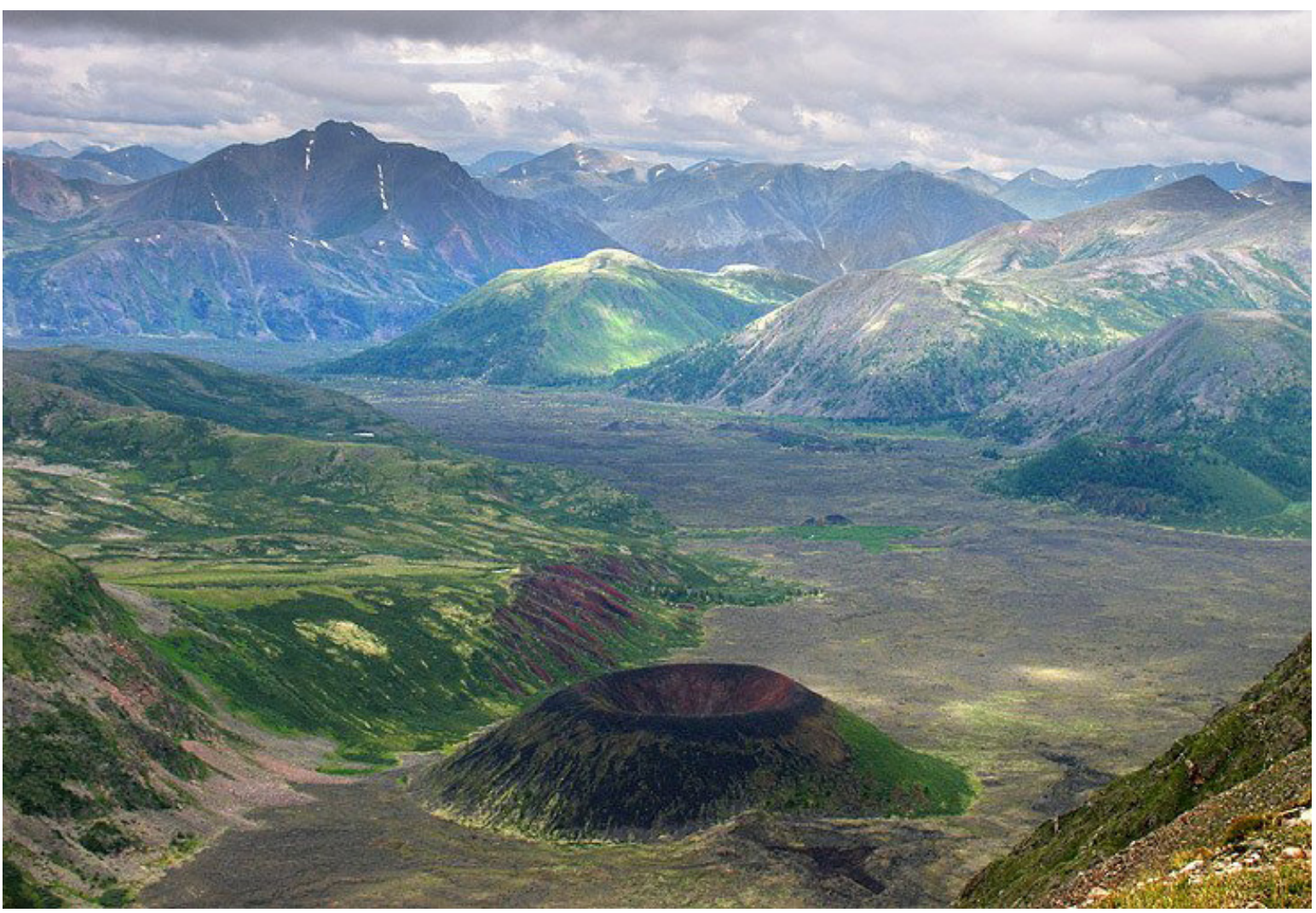

Pис. 6. Долина вулканов, верховье р. Жом-Болок. Фото В. Мориссона, Google Earth, 2005 2.

Fig. 6. Valley of volcanoes, the upper stream of Zhom-Bolok. Photo by V. Morrison, Google Earth, 2005.

${ }^{1}$ По сведениям С. И. Вайнштейна, род тувинцев-тоджинцев, происходит от племени Чооду (Вайнштейн, 1961: 37). 
вокруг. И вместо цветущей долины осталась лишь каменная черная ${ }^{1}$ долина» (Сугоракова, Монгуш, 2015: 100).

Комментарий А. М. Сугораковой, которая давала интервью Т. Рамазановой: «И мы, члены экспедиции, когда слушали, как раз сидели на этом месте месте застывшей лавы. Судя по всему, этот факт случился недавно, несколько тысяч лет назад, раз люди еще в легендах рассказывают о том, что у них текли огненные реки. Если человеческая память это сохранила, значит, такой факт вполне мог быть» (Рамазанова, 2012: 36).

В монографии «Кайнозойский вулканизм Тувы» данный эпизод изложен в следующем виде: «...в легендах местных оленеводов, как тувинских, так и бурятских, рассказывается об огненной реке, потекшей вместо воды (змее, выползшей на поверхность) и уничтожившей одно из племен» (Сугоракова и др., 2003: 47).

В прошлом году были опубликованы результаты датировки возраста базальтовых лав в долине р. Жом-Болок (рис. 5, 6). Они показали, что вул-

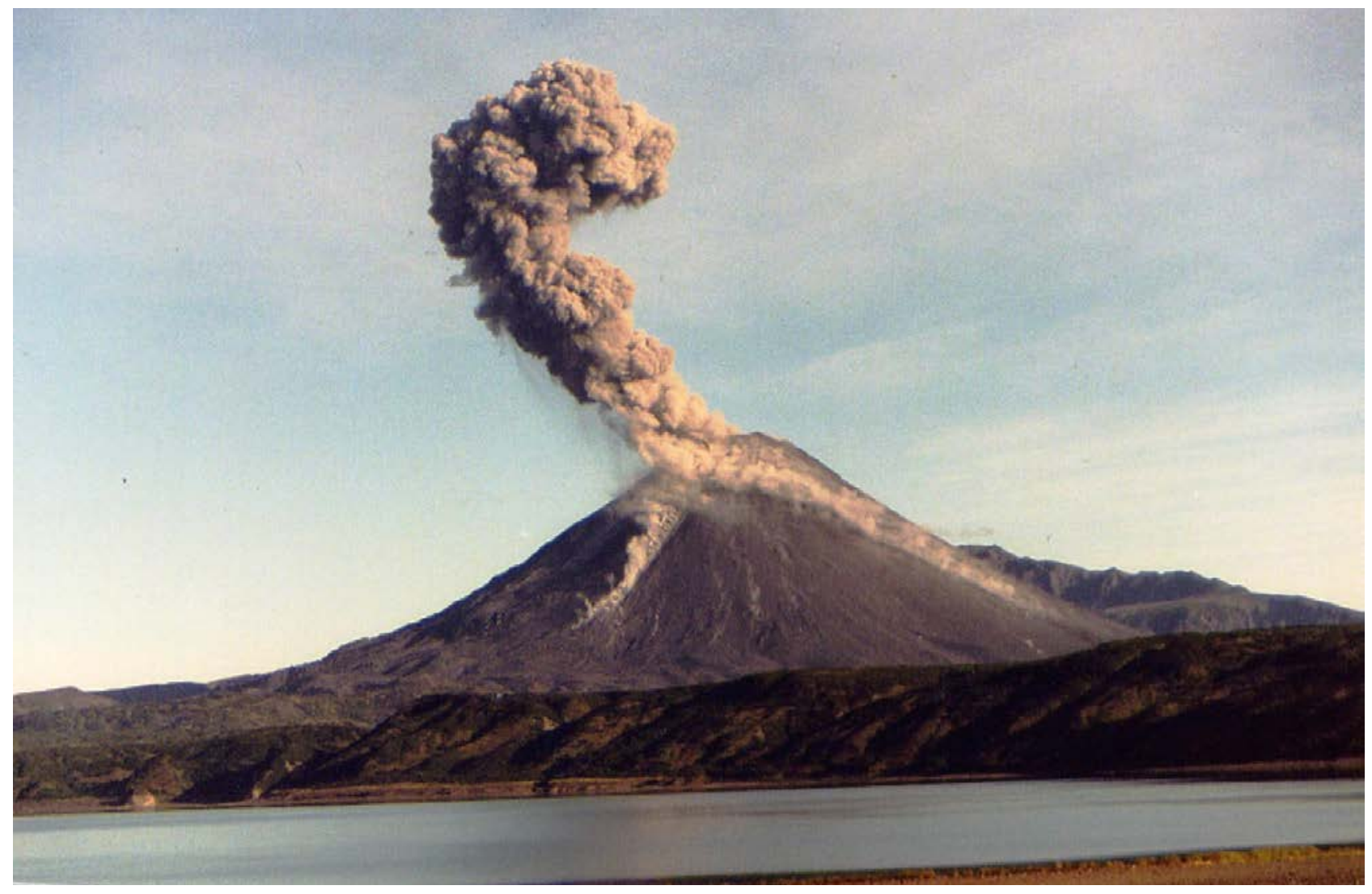

Рис. 7. Вулкан Шивелуч, Камчатка (Мультимедийное приложение ..., Электр. ресурс). Fig. 7. Shiveluch volcano, Kamchatka (Mul'timediinoe prilozhenie ..., online).

\footnotetext{
${ }^{1}$ Вулканические породы имеют черные, серые, темно-бурые, ржаво-коричневые цвета. Именно поэтому, по мнению Т. Н. Прудниковой, появилось известное словосочетание "Отюкенская чернь" (Прудникова, 2017).
} 
канические извержения первого этапа здесь начались немногим более 13 тыс. лет назад, а наиболее молодые лавы четвертого этапа излились около 1 тыс. лет назад (Аржанников и др., 2017). Таким образом, геохронологические данные свидетельствуют о достоверности легенд оленеводов в той части, что наши предки могли воочию наблюдать вулканические извержения.

На основе вышесказанного и этимологических построений Б. И. Татаринцева (Татаринцев, 2008: 360-363) предлагаем следующую версию.

В основе слова өдүген лежит многозначный тюркский глагол өm-, и структура слова такая же, что и по Б. И. Татаринцеву: глагольная основа өm + аффикс (a)k, образующий отглагольное имя, + формант $(a)$, образующий имя отыменное, но глагол не значении 'пробивать, просверливать' (там же: 363), а в значении 'оправляться, испражняться'. В тувинском языке есть слово өдек $(ө т$ + (а)к) - “навоз; кал, помёт скота, животных; место, где находится юрта; территория стойбища (аала) и его окрестности” (там же: 359). При добавлении к $ө m(a) k$ форманта (a)н получаем имя собственное, обозначающее место, где находятся продукты переработки деятельности кого-либо, а в данном случае - современного или молодого вулкана. Ассоциирование извержения вулкана с процессом оправления естественной надобности представителями животного мира для современного читателя может показаться непривычным, неблагозвучным и т. п. Тем не менее, представление об извержении вулкана в значении 'испражнение Земли' является, на наш взгляд, вполне адекватным.

Таким образом, по нашему мнению, выброс вулканических газов и пепла, извержение лавы (рис. 7, 8) - это “испражнения” из недр матери-Земли, поэтому места, содержащие продукты вулканических извержений, получили наименование Өдүген.

Поскольку значительная часть территории Восточного Саяна покрыта позднекайнозойскими, т. е. в геологическом отношении молодыми вулканами, то логично будет считать, что исходным названием этой горной системы было Өдүген.Большинство позднекайнозойских вулканических пород на территории Восточного Саяна было образовано, конечно, в доисторическое время, до появления вида Homo sapiens. Однако, любой человек, хоть раз видевший изверженные породы современного вулкана (рис. 3, 9, 10, 12), которые и по форме своей похожи на өдек, не спутает их с другими горными породами и сможет определить их относительно древние аналоги в других местах.

Другие этимологические аспекты слова өдуген косвенно подтверждают основную вулканическую версию его происхождения.

Как сообщил наш информант С. М. Оюн:

“Бедик, тас, дески, ивижилерниң чайлаар харлыг, мензилиг черлерин ӨдугенТайга дээр. Иви изигге шыдашпас, ынчангаш сериин черлер херек, ымыраа-сээк ында чок, иви оъду эңдерик”. 


\section{Перевод с тувинского языка:}

“Одуген-Тайгой называют высокие, голые, ровные места с нерастаявшими снежниками, на которых проводят лето оленеводы. Олень не выносит жару, поэтому ему нужны прохладные места. Там [на Одугене] нет летающих насекомых, а ягеля - полно”.

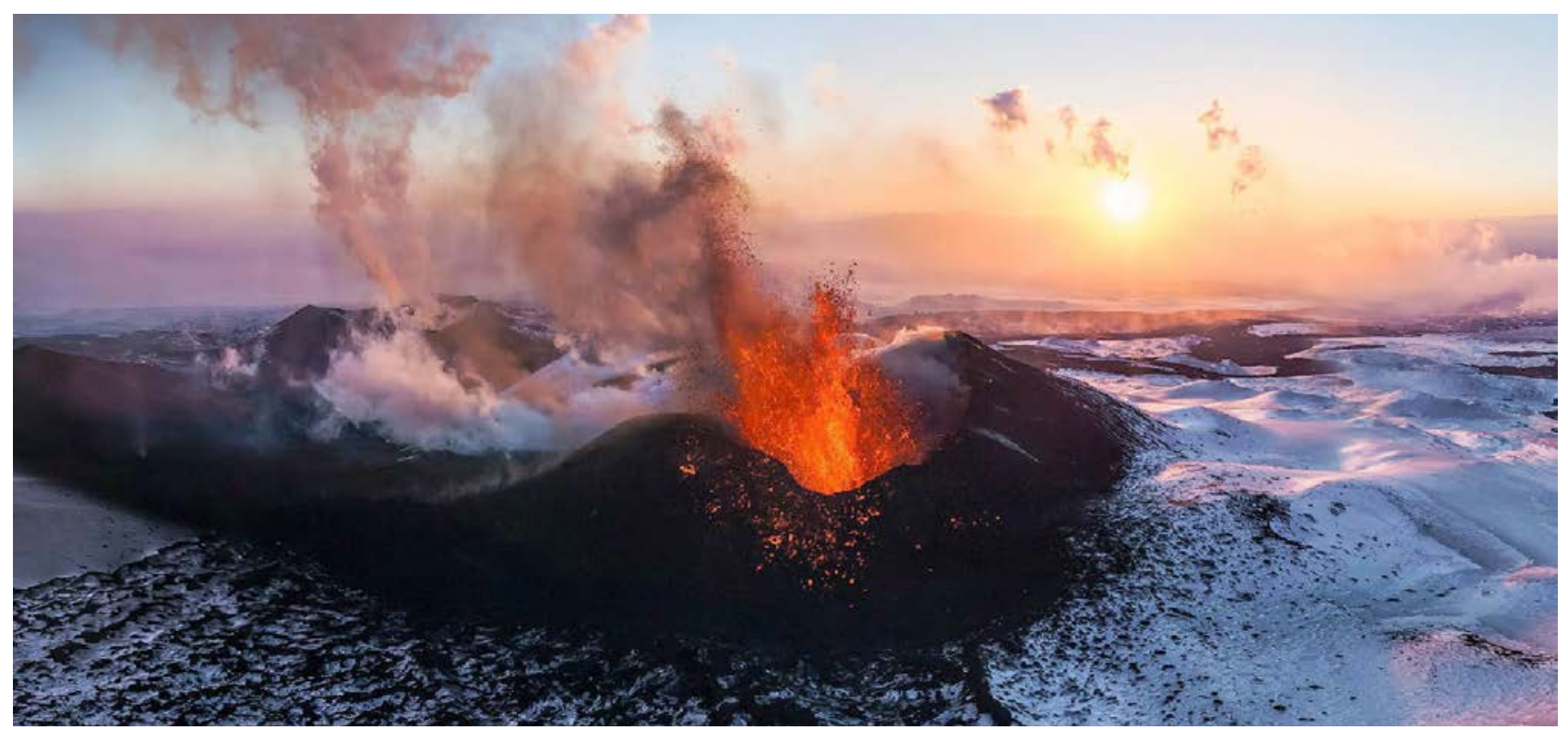

Рис. 8. Извержение вулкана Толбачик, Камчатка (Мультимедийное приложение ..., Электр. ресурс). Fig. 8. The eruption of Tolbachik volcano, Kamchatka (Mul'timediinoe prilozhenie ..., online).

Аналогичные сведения имеются также в обширной словарной статье өдуген (Татаринцев, 2008: 360-363). По всей видимости, здесь имеются в виду высокогорные плато - один из типичных ладшафтов Восточного Саяна. А как раз этот тип ладшафта представлен в основном лавовыми плато (рис. 5), что подчеркивает взаимную связь сведений о местности Өдүген как высокогорных участков с относительно ровной поверхностью и геологических данных о проявлениях плато-базальтового вулканизма.

Сведения своих тоджинских информаторов о том, что өдуген означает: 1) “легко (или 'обычно, часто, быстро') проходимый”, 2) “быстро намокающий, промокающий (в ненастную погоду)”, Б. И. Татаринцев считает сомнительными и недостаточно убедительными (там же: 362). Эти мотивировки названия являются, скорее всего, вторичными и вытекают из особенностей высокогорного ландшафта типа плато: во-первых, относительно ровная поверхность плато обуславливает ее относительно легкую проходимость, во-вторых, безлесная поверхность плато обуславливает как быстрое намокание от атмосферных осадков, так и необходимость быстрого пересечения плато в виду отсутствия дров для обогрева и приготовления пищи. Такие специфические условия более всего характеризуют Восточно-Тувинское лавовое нагорье, которое оленеводы восточной части Тоджи называют Өдүген-Тайга. 


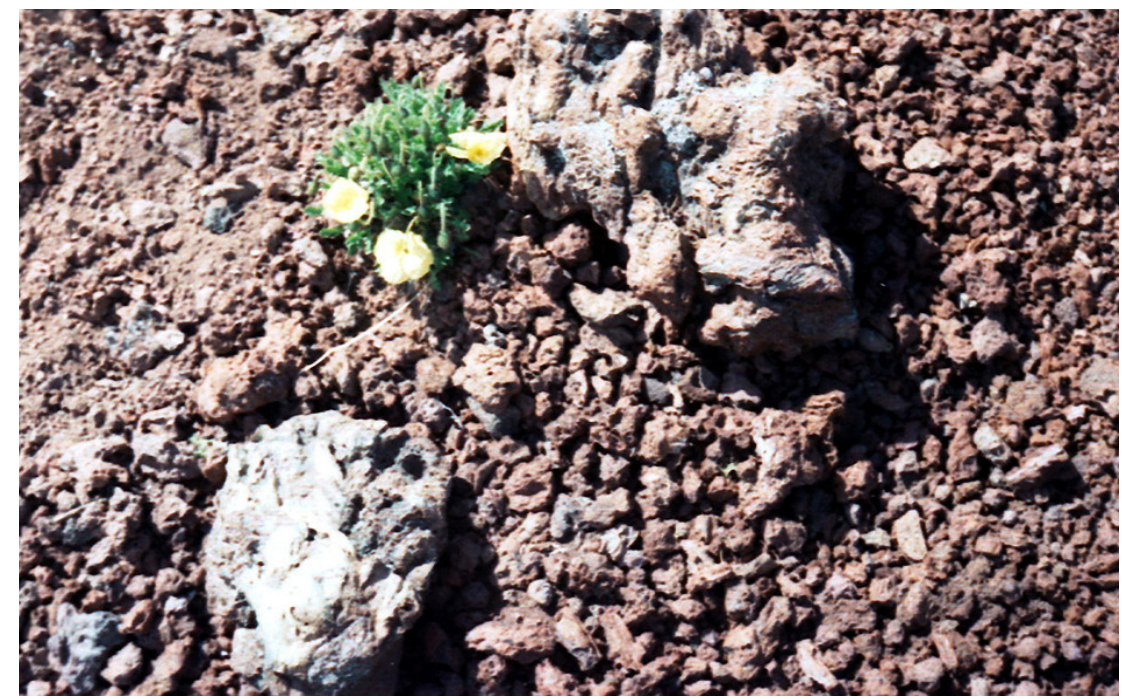

В монгольских языках слово ötügen etügen означает “божество земли ; сама земля, рассматриваемая как божественная" (там же: 361). Многие исследователи, в частности, П. Пеллью, Л. П. Потапов , Б. И. Татаринцев и другие, считают его тюркизмом (там же: 361-362).

Рис. 9. Вулканические бомбы среди вулканического шлака, Восточно-Тувинское лавовое нагорье (плато Өдуген).

Фото А. Сугораковой, 1998 г.

Fig. 9. Volcanic bombs among the volcanic slag, the Eastern-Tuva lava highland (plateau

Odugen), photo by A. Sugorakova, 1998.

По мнению Л. П. Потапова,

«Ötükän стал божеством земли не только у древнеорхонских тюрков, но и у монголов. Каким же образом это могло произойти? Здесь, конечно, возможны только предположения. Основной

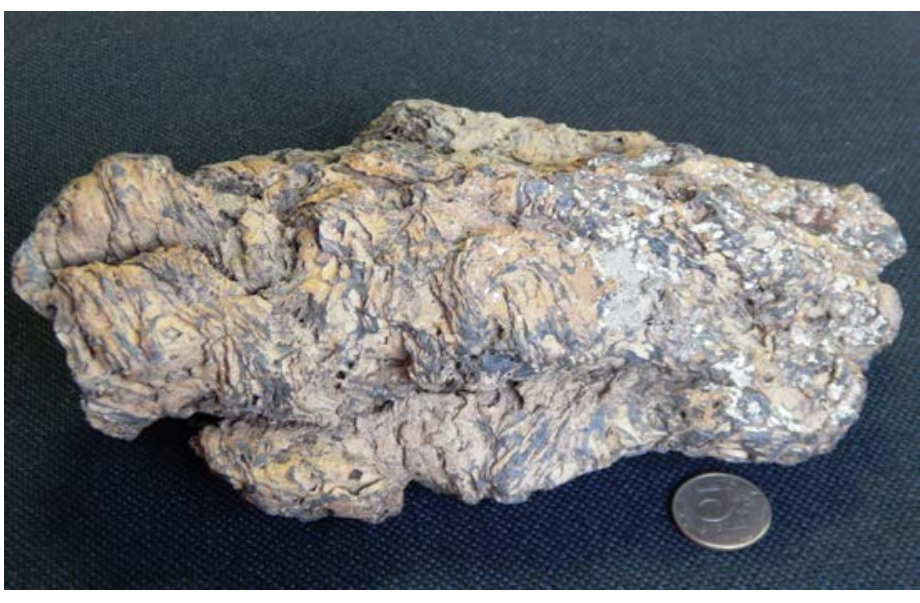

Рис. 10. Образеи базальта из лавовой “реки” Кыштаг (из коллекции А. М. Сугораковой 2005 года). Фото автора, 2017 2.

Fig. 10. A sample of basalt from a lava "river" Kushtag (from A.M. Sugorakova's 2005 collection). Photo by the author, 2017. причиной было, видимо, участие в этногенезе монголов некоторых древнетюркских племен и родов, ассимилировавшихся в монголоязычной среде. Отдельные древнетюркские племена и роды, восприняв монгольский язык, не могли не внести в монгольскую среду своих различных, веками сложившихся элементов культуры и быта и особенно своих древних религиозных культов и традиций, тюркское происхождение которых со временем было забыто. Именно так могло появиться и сохраниться у монголов название Ötükän в несколько измененной фонетической форме» (Потапов, 1957: 116-117).

\section{Хангайский Отюкен (Ötükän)}

На северном подножии Хангайского нагорья - верховьях р. Тэс и на правобережье р. Селенга, в т. ч. в бассейне р. Орхон-Гол и Тариатской впадине, 
водораздельной части северного и южного Хангая, а также на южных склонах и подножье Хангая широко распространены позднекайнозойские вулканические породы базальтового состава (рис. 11). Они представлены лавовыми плато на некоторых вершинах хангайских гор и на подножьях Хангая, лавовыми “реками” и полями в долинах pp. Орхон, Урд-Тамир, Хойд-Тамир, Хунуй, Хануй, Чулуут, Сумын, Тэрхийн и др., шлаковыми конусами вулканов, например, вулкана Хорго.

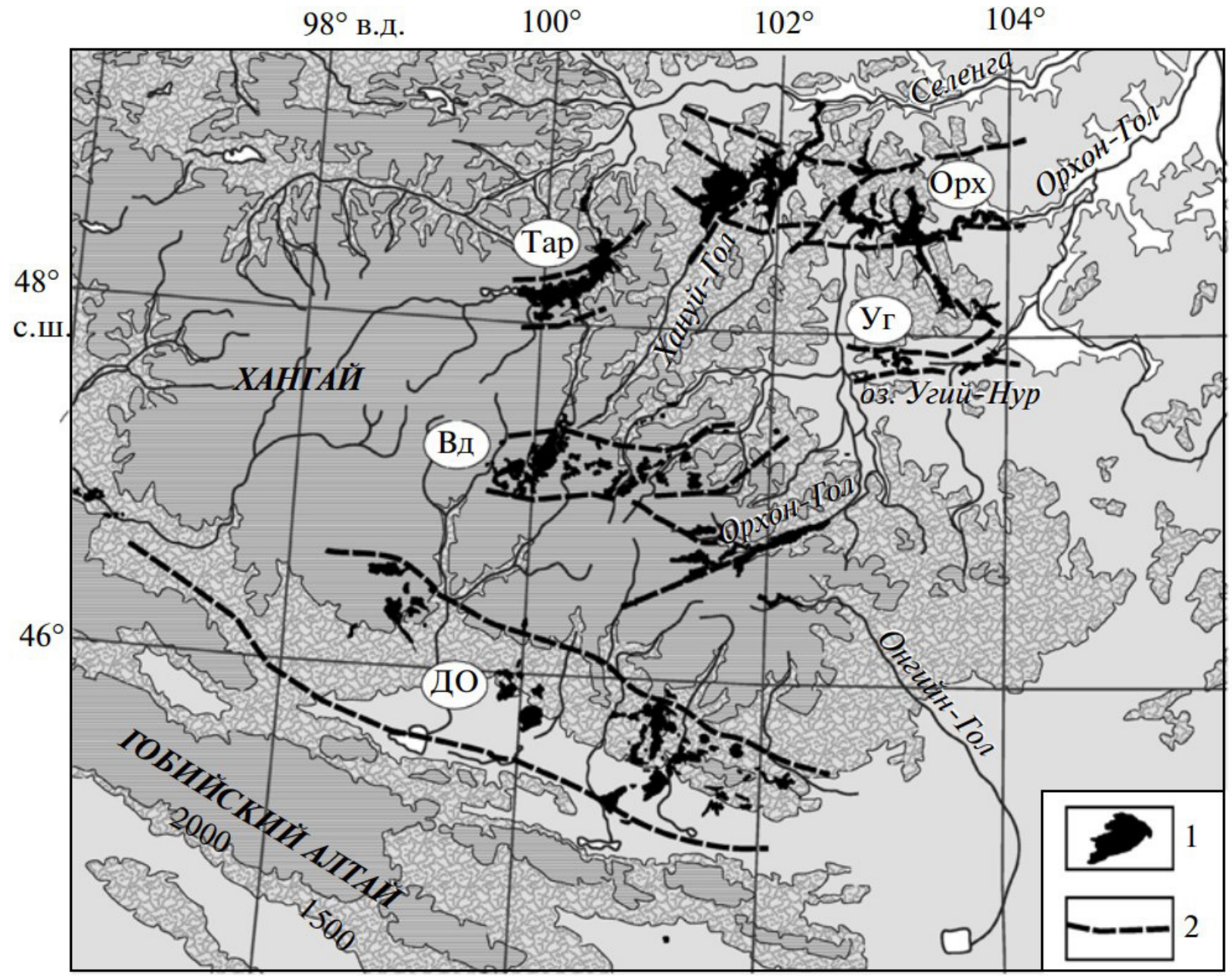

Рис. 11. Позднекайнозойский ареал Хангайской вулканической области.

1 - лавы; 2 - разломы (по: Ярмолюк и др., 2011: 346).

Fig. 11. Late Cenozoic areal Khangai volcanic region. 1 - lava; 2 - faults (Yarmolyuk et al., 2011: 346).

На основе этих данных, а также предлагаемой нами этимологии слова $\Theta \partial \gamma_{-}$ ген и при Өдуген = Ötükän, можно предположить, что в указанном районе Хангайского нагорья и находилась местность, известная из древнетюркских рунических надписей под названием Ötükän. Эта местность являлась политическим и сакральным центром нескольких могучих средневековых кочевых империй (Дробышев, 2012: 5). 


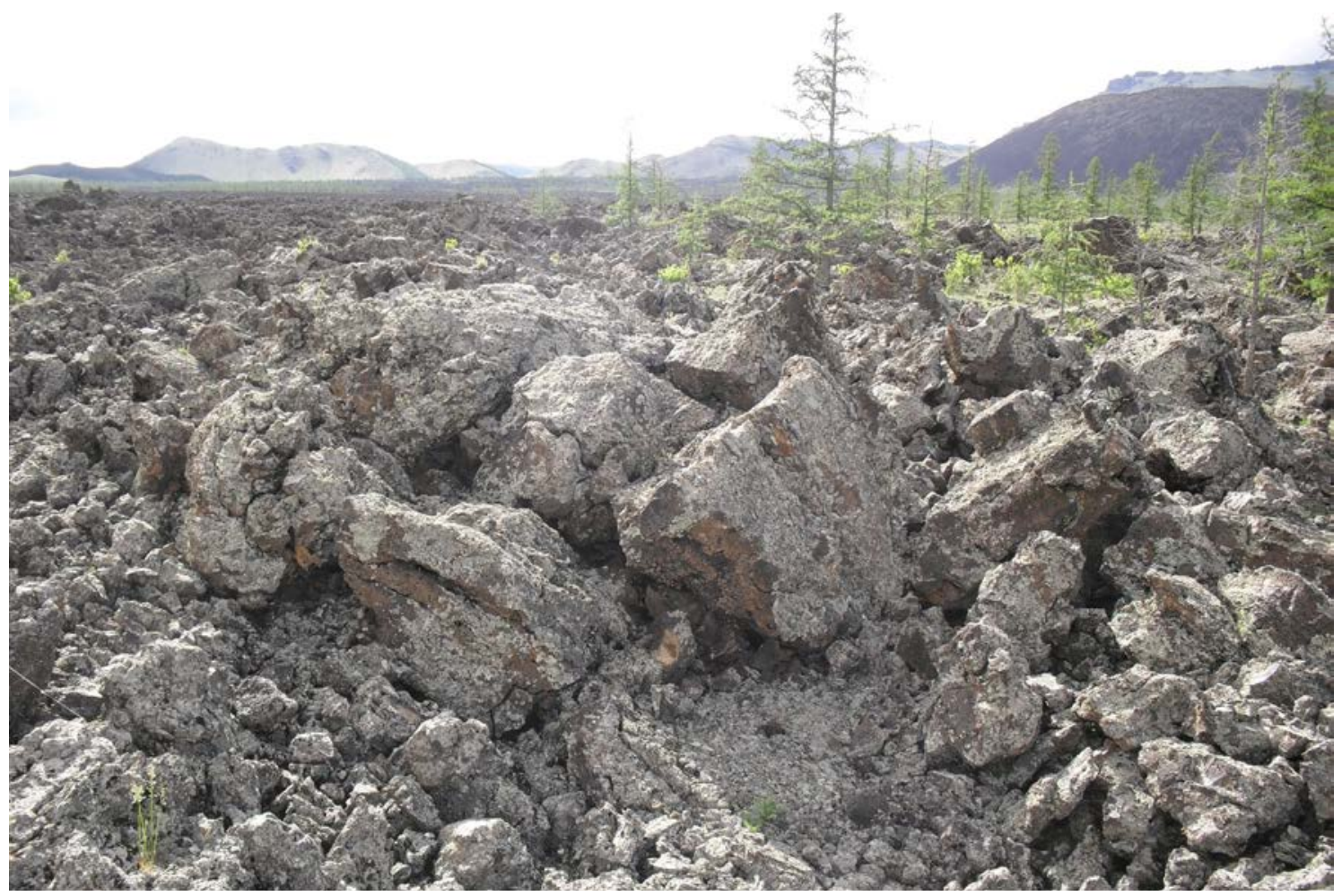

Рис. 12. Лавовое поле в Тариатской впадине, Хангай, Монголия.

В правом верхнем углу - конус вулкана Хорго. Фото автора, 2010 г.

Fig. 12. Lava field in Tariat depression, Khangai, Mongolia. In the upper right corner, the cone of Horgo volcano. Photo by the author, 2010.

Таким образом, выделяется две местности с аналогичными по происхождению названиями Өдуген в Восточном Саяне и Ötükӓn в Хангае, при этом второе название в качестве топонима использовалось лишь до эпохи средневековых монголов. По мнению Ю. И. Дробышева, во времена Монгольской империи местность Отюкен называлась Кара-Корум (Дробышев, 2012: 18-20). С геологической стороны, эта точка зрения также не лишена оснований, поскольку Кара-Корум, «осыпь черных камней» (Древнетюркский словарь, 1969: 460), по всей видимости, характеризует местность, где в большом количестве находятся россыпи вулканических пород на поверхности лавовых «рек» и плато, осыпи на склонах образованных лавами речных террас и шлаковых конусов вулканов. Все эти вулканиты имеют окраску от черного до серого и бурого (рис. 12).

\section{Заключение}

Итак, исторические и фольклорные свидетельства о том, что Өдүген / Ötükän - это две местности в Восточном Саяне и Хангае, полностью совпадают с геологическими данными - в Центральной Азии проявления позднекайнозойского вулканизма находятся лишь в горных областях Восточного Саяна (включая район к югу от Байкала) и Хангая (включая верхнее 
течение р. Тэс). Другими словами, исторические и фольклорные сведения о данном топониме и геологические данные о наиболее молодом вулканизме указывают на одни и те же местности в Восточном Саяне и Хангае.

В заключении сделаем ремарку относительно текста известной в Туве народной песни “Өдуген-Тайга”, которая начинается со строк: “Өдуген-Тайга чурттуг-ла мен, өлең сиген чыттыг-ла мен...” - “Одуген-Тайга - земля моя, травой осокой пахну я...” Однако, по словам М. Б. Севека, который родился и вырос в семье оленеводов, летом кочевавших в районе плато Өдүген, вместо “өлең сиген чыттыг-ла мен” - 'травой осокой пахну я', в первоначальном тексте пелось: “өгээмчизиг чыттыг-ла мен” - 'запахом багульника пахну я’.

Действительно, багульник, богатый эфирными маслами, среди таежных растений издает, пожалуй, самый сильный специфический запах. Как пояснил М. В. Севек, от тех, кто долго пробыл в тайге, пахнет багульником, и значение названия өгээмчи (багульник) заключено в самом слове - өге эмчи, где өге глагольная основа со значением 'тереться; мазаться, пачкаться', эмчи - ‘лекарь'.

Этому растению посвящены также стихи тувинского педагога Лидии Ооржак:

Тулаа-шыктыг черге өзер

Турум чурту - тайга-таңды.

Өскен черниң эм үнүжү

Өвээнчиниң ${ }^{1}$ чыды чаагай.

Тош ${ }^{2}$ аңнап аъттанганда,

Тожу оглу мынчаар ырлаар:

“Өдуген тайга чурттуг-ла мен,

Өвээнчи сиген чыттыг-ла мен” (Монгуш, 2014: 46).

Подстрочный перевод:

В болотисто-луговой земле растущий

Постоянное его местонахождение - горная тайга.

Растущей земли лечебного растения

Багульника запах приятный.

На охоту на лося отправляясь верхом,

Сын Тоджи вот так поет:

“Одуген тайга земля моя,

Багульником травой пахну я”.

${ }^{1}$ Өвээмчи и өгемчи являются синонимами (Тувинско-русский словарь, 1968: 331).

${ }^{2}$ Toш - название лося на тоджинском диалекте тувинского языка. Вероятно, этому животному обязано появление названия местности Тожу < Тош уу - лосиная страна: в рационе лося, как известно, значительную роль играют водные и околоводные растения, а Тоджинская котловина изобилует местами, где они растут - озерами и болотами. 


\section{СПИСОК ЛИТЕРАТУРЫ}

Аржанников, С. Г., Иванов, А. В., Аржанникова, А. В., Демонтерова, Е. И., Жоливе, М., Воронин, В. И., Буянтуев, В. А., Осколков, В. А. (2017) Возраст Жомболокского лавового поля (Восточный Саян) по дендрохронологическим и радиоуглеродным данным // Геология и геофизика. T. 58. № 1. C. 27-47. DOI: 10.15372/GiG20170103

Вайнштейн, С. И. (1961) Тувинцы-тоджинцы. Историко-этнографические очерки. М. : Наука. 219 с.

Гросвальд, М. Г. (1965) Развитие рельефа Саяно-Тувинского нагорья. М. : Наука. 168 c.

Мультимедийное приложение к учебнику Е. М. Домогацких, Н. И. Алексеевского «География». 8 класс [Электронный ресурс] // Издательство «Русское слово». URL: http:// http://pусское-слово.pф/catalog/catalogs/srednyaya-shkola-5-9/geografiya-5-9-klass/geografiya-8-klass/ (дата обращения: 30.07.2018).

Доржу, Ч. М. (2015) Мен тыва мен [Я - тувинец]. Кызыл : б/и. 224 а. (На тув. яз.).

Допчун-оол, К. Т. (2015) Верховный шаман Тувы об артыше // Плюс Информ (газета). 9 февраля. С. 34.

Древнетюркский словарь (1969) / ред. В. М. Наделяев, Д. М. Насилов, Э. Р. Тенишев, А. М. Щербак. Л. : Наука. 679 с.

Дробышев, Ю. И. (2012) Средневековый Отюкен // Восток (Oriens). № 4. С. 5-22.

Монгуш, К. Ш. (2014) Бойдус үжүглели [Словарь природы]. Кызыл : Национал школа хөгжүдер институт. 128 с. (На тув. яз.)

Ондар, Б. К. (2007) Топонимический словарь Тувы. Кызыл : Тув. кн. изд-во. $552 \mathrm{c.}$

Оюн, Д. (2006) Где находится Одуген-тайга? [Электронный ресурс] // ИА ТуваОнлайн. 29 августа. URL: http://www.tuvaonline.ru/2006/08/29/odugen-taiga.html (дата обращения 30.08.2017).

Потапов, Л. П. (1957) Новые данные о древнетюркском Ötükän // Советское востоковедение. № 1. С. 106-117.

Прудников, С. Г. (2005) Вулканизм и покровные оледенения Тувы // Природа. № 8. С. 49-60.

Прудникова, Т. Н. (1997) Древние культы, мифы и загадки Тувы // Устойчивое развитие малых народов Центральной Азии и степные экосистемы : сборник трудов 5 Убсунурского международного симпозиума, 27 июля -3 августа 1997 г. : в 2-х т. Кызыл ; М. : Изд-во Слово. Т. 2.360 с. С. 293-296.

Прудникова, Т. Н. (2017) Священный Одуген и процессы современного вулканизма // Успехи современной науки. Т. 2. № 8. С. 160-163. 
Рамазанова, Т. (2012) Пока вулканы в Туве «спят» // Плюс Информ. 26 марта. C. 36.

Расспросные речи в посольском приказе атамана Тарского города В. Тюменца и десятника И. Петрова о их поездке к Алтын-хану (1959) // Материалы по истории русско-монгольских отношений. Русско-монгольские отношения. 1607-1636. Сборник документов / отв. ред. Л. М. Гатауллина. М. : Издательство восточной литературы. 350 с. С. 59-66.

Субракова, О. В. (2006) Хакасско-русский словарь / Хакас-орыс сӧстік. М. : Наука. 1115 с.

Сугоракова, А. М., Монгуш, А. А. (2015) Новейший вулканизм Восточной Тувы и подтверждение древней легенды // Сейсмическая безопасность региона и воздействие сейсмогеологических и социально-экономических факторов на его развитие: Материалы Всероссийской научно-практической конференции (17-18 ноября 2015 года, Кызыл, Россия) / отв. ред. В. И. Лебедев. Кызыл : ТувИКОПР СО РАН. 109 с. С. 100-101.

Сугоракова, А. М., Ярмолюк, В. В., Лебедев, В. И. (2003) Кайнозойский вулканизм Тувы. Кызыл : ТувИКОПР СО РАН. 92 с.

Татаринцев, Б. И. (2008) Этимологический словарь тувинского языка. Новосибирск : Наука. T. IV. 442 с.

Тувинско-русский словарь (1968) / отв. ред. Э. Р. Тенишев. М. : Изд-во «Советская энциклопедия». 646 с.

Чадамба, Е. Л. (2014) Леонид Чадамба. Из озера света [Электронный ресурс] // Центр Азии (газета), № 30 (8-14 августа). URL: http://www.centerasia.ru/ issue/2014/30/5056-leonid-chadamba.-iz-ozera-sveta.html (дата обращения 13.04.2017).

Ярмолюк, В. В., Козловский, А. М., Кудряшова, Е. А., Лебедев, В. И., Сугоракова, А. М. (2004) Крупнейшие долинные излияния в кайнозое Азии: особенности строения, состава и условия формирования «лавовой реки» долины Малого Енисея // Вулканология и сейсмология. № 4. С. 3-20.

Ярмолюк, В. В., Кудряшова, Е. А., Козловский, А. М., Лебедев, В. А. (2008) Позднекайнозойский вулканизм Хангая (Центральная Монголия) и проблемы новейшего горообразования в Центральной Азии // Доклады академии наук. T. 422. № 2. С. 223-228.

Ярмолюк, В. В., Кудряшова, Е. А., Козловский, А. М., Саватенков, В. М. (2011) Позднекайнозойская вулканическая провинция Центральной и Восточной Азии // Петрология. Т. 19. № 4. С. 341-362. 


\section{REFERENCES}

Arzhannikov, S. G., Ivanov, A. V., Arzhannikova, A. V., Demonterova, E. I., Zholive, M., Voronin, V. I., Buiantuev, V. A. and Oskolkov, V. A. (2017) Vozrast Zhombolokskogo lavovogo polia (Vostochnyi Saian) po dendrokhronologicheskim i radiouglerodnym dannym [Age of the Jombolok lava field (East Sayan): evidence from dendrochronology and radiocarbon dating]. Geologiia i geofizika, vol. 58, no. 1, pp. 27-47. DOI: $10.15372 / \mathrm{GiG} 20170103$

Vainshtein, S. I. (1961) Tuvintsy-todzhintsy. Istoriko-etnograficheskie ocherki [Tozhu tuvans: historical and ethnographic essays]. Moscow, Nauka. 218 p. (In Russ.).

Grosval'd, M. G. (1965) Razvitie rel'efa Saiano-Tuvinskogo nagor'ia [The development of the relief of the Sayan-Tuva highlands (glaciation, volcanism, neotectonics)]. Moscow, Nauka, 168 p. (In Russ.).

Mul'timediinoe prilozhenie k uchebniku E. M. Domogatskikh, N. I. Alekseevskogo «Geografiia». 8 klass [Multimedia aids to the textbook "Geography. Class 8"]. Izdatel'stvo «Russkoe slovo» [online] Available at: http:// http://russkoe-slovo.rf/catalog/catalogs/srednyaya-shkola-5-9/geografiya-5-9-klass/geografiya-8-klass/ (access data: 30.07.2018). (In Russ.).

Dorzhu, Ch. M. (2015) Men Tyva men [I'm Tuvan]. Kyzyl, 224 p. (In Tuvan).

Dopchun-ool, K. T. (2015) Verkhovnyi shaman Tuvy ob artyshe [The supreme shaman of Tuva on the artysh]. Plius Inform (newspaper), 9 February, p. 34. (In Russ.).

Drevnetiurkskii slovar' [An old Turkic dictionary] (1969) / ed. by V. M. Nadeljaev, D. M. Nasilov, E. R. Tenishev and A. M. Shcherbak. Leningrad, Nauka. 679 p. (In Russ.).

Drobyshev, Iu. I. (2012) Srednevekovyi Otiuken [The Medieval Otuken]. Vostok (Oriens), no 4, pp. 5-22. (In Russ.).

Mongush, K. Sh. (2014) Boidus yzhygleli [A Dictionary of nature]. Kyzyl, Natsional shkola khegzhyder institute. 128 p. (In Tuvan).

Ondar, B. K. (2007) Toponimicheskii slovar' Tuvy [A Toponymical dictionary of Tuva]. Kyzyl, Tuvinskoye knizhnoye izdatel'stvo. 552 p. (In Russ.).

Oiun, D. (2006) Gde nakhoditsia Odugen-taiga? [Where is the Odugen taiga?]. Tuva-Online, 29 August [online] Available at: http://www.tuvaonline.ru/2006/08/29/ odugen-taiga.html (access data: 30.08.2017). (In Russ.).

Potapov, L. P. (1957) Novye dannye o drevnetiurkskom Ötükän [New data on Old Turkic Ötükän]. Sovetskoe vostokovedenie, no 1, pp. 106-117. (In Russ.).

Prudnikov, S. G. (2005) Vulkanizm i pokrovnye oledeneniia Tuvy [Volcanism and cover glaciation of Tuva]. Priroda, no. 8 (1080), pp. 49-60. (In Russ.).

Prudnikova, T. N. (1997) Drevnie kul'ty, mify i zagadki Tuvy [Ancient cults, myths and mysteries of Tuva]. In: Ustoichivoe razvitie malykh narodov Tsentral'noi Azii i stepnye ekosistemy [Sustainable development of small peoples of Central Asia and steppe 
ecosystems]: collection of materials of the 5th Ubsunur international Symposium, July 27-August 3, 1997 : in 2 vol. Moscow, Slovo Publ., vol. 2, 360 p., pp. 294-296. (In Russ.).

Prudnikova, T. N. (2017) Sviashchennyi Odugen i protsessy sovremennogo vulkanizma [The sacred Odugen and processes of modern volcanism]. Uspekhi sovremennoi nauki, vol. 2, no 8, pp. 160-163. (In Russ.).

Ramazanova, T. (2012) Poka vulkany v Tuve «spiat» [While volcanoes in Tuva «sleep»]. Plius Inform (newspaper), 26 Mars, p. 36 [online] Available at: http://plusinform.ru/main/3423-poka-vulkany-v-tuve-spyat.html (access data: 30.08.2017). (In Russ.).

Rassprosnye rechi v posol'skom prikaze atamana Tarskogo goroda V. Tiumentsa i desiatnika I. Petrova o ikh poezdke k Altyn-khanu [Questioning speeches in the Embassy order of the ataman of Tara V. Tyumentsev and I. Petrov's foreman about their trip to Altyn Khan] (1959). In: Materialy po istorii russko-mongol'skikh otnoshenii. Russko-mongol'skie otnosheniia. 1607-1636 [Materials on the history of RussianMongolian relations. Russian-Mongolian relations. 1607-1636] : a collection of documents / ed. by L. M. Gataullina. Moscow, Izdatel'stvo vostochnoi literatury. 350 p. Pp. 59-66. (In Russ.).

Subrakova, O. V. (2006) Khakassko-russkii slovar'. Khakas-orys söstik [A KhakassRussian dictionary]. Moskaw, Nauka. 1115 p. (In Russ.).

Sugorakova, A. M. and Mongush, A. A. (2015) Noveishii vulkanizm Vostochnoi Tuvy i podtverzhdenie drevnei legendy [The latest volcanism in the Eastern Tuva and the confirmation of the ancient legend]. In: Seismicheskaia bezopasnost' regiona $i$ vozdeistvie seismogeologicheskikh i sotsial'no-ekonomicheskikh faktorov na ego razvitie [Seismic safety of the region and the impact of seismogeological and socio-economic factors on its development]: Materials of the all-Russian scientific and practical conference (17-18 November 2015, Kyzyl, Russia / ed. by V. I. Lebedev. Kyzyl, TuvIKOPR SO RAN. 109 p. Pp. 100-101. (In Russ.).

Sugorakova, A. M., Yarmolyuk, V. V. and Lebedev, V. I. (2003) Kainozoiskii vulkanizm Tuvy [Cenozoic volcanism of Tuva]. Kyzyl, TuvIKOPR SO RAN. 92 p. (In Russ.)

Tatarintsev, B. I. (2008) Etimologicheskii slovar' tuvinskogo iazyka [An Etymological dictionary of the Tuvan language]. Novosibirsk, Nauka. Vol. IV. 442 p. (In Russ.).

Tuvinsko-russkii slovar' [A Tuvan-Russian dictionary] (1968) / ed. by E. R. Tenishev. Moscow, Sovetskaia entsiklopediia. 646 p. (In Russ.).

Chadamba, E. L. (2014) Leonid Chadamba. Iz ozera sveta [Leonid Chadamba. From the lake of light]. Tsentr Azii (newspaper), no. 30 (8-14 August) [online] Available at: http://www.centerasia.ru/issue/2014/30/5056-leonid-chadamba.-iz-ozera-sveta. html (access data: 30.08.2017). (In Russ.). 
Iarmoliuk, V. V., Kozlovskii, A. M., Kudriashova, E. A., Lebedev, V. I. and Sugorakova, A. M. (2004) Krupneishie dolinnye izliianiia v kainozoe Azii: osobennosti stroeniia, sostava i usloviia formirovaniia «lavovoi reki» doliny Malogo Eniseia [Major Valley Lava Flows in Asia During Cenozoic Times: Structure, Composition, and the Environment of the "Lava River" Forming in the Lesser Enisey River Valley]. Journal of Volcanology and Seismology, no. 4, pp. 3-20. (In Russ.).

Iarmoliuk, V. V., Kudriashova, E. A., Kozlovskii, A. M., Lebedev, V. A. (2008) Pozdnekainozoiskii vulkanizm Khangaia (Tsentral'naia Mongoliia) i problemy noveishego goroobrazovaniia v Tsentral'noi Azii [Late cenozoic volcanism of Khangai (Central Mongolia): evidence for recent orogeny in Central Asia]. Doklady Akademii Nauk, vol. 422, no. 2, pp. 223-228. (In Russ.).

Iarmoliuk, V. V., Kudriashova, E. A., Kozlovskii, A. M. and Savatenkov, V. M. (2011) Pozdnekainozoiskaia vulkanicheskaia provintsiia Tsentral'noi i Vostochnoi Azii [Late Cenozoic volcanic province in Central and East Asia]. Petrology, vol. 19, no. 4, pp. 341-362. (In Russ.).

Submission date: 30.08 .2017$.

\section{Для цитирования:}

Монгуш А. А. Местность Өдүген: расположение, этимология и связь с хангайским аналогом [Электронный ресурс] // Новые исследования Тувы. 2018, № 3. URL: https:/nit.tuva.asia/nit/article/view/791 (дата обращения: дд.мм.гг.). DOI: 10.25178/ nit.2018.3.7

\section{For citation:}

Mongush A. A. Odugen: location, etymology and linkage with the Hangai analogue. The New Research of Tuva, 2018, no. 3 [on-line] Available at: https://nit.tuva.asia/nit/article/ view/791 (accessed: ...). DOI: 10.25178/nit.2018.3.7 